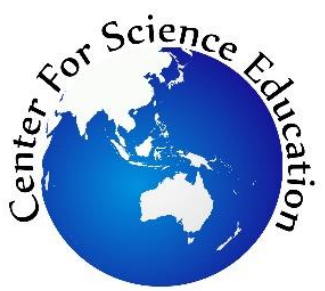

Tersedia online di EDUSAINS

Website: http://journal.uinjkt.ac.id/index.php/edusains

EDUSAINS,13(2), 2021, 195-204

Research Artikel

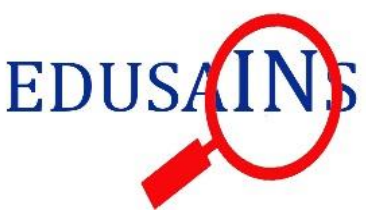

PENGEMBANGAN E-MODULE INTERAKTIF SIFAT KOLIGATIF LARUTAN MENGGUNAKAN APLIKASI SIGIL

\title{
DEVELOPMENT OF INTERACTIVE E-MODULE ON COLLIGATIVE PROPERTIES OF SOLUTIONS USING SIGIL
}

\author{
Raviqa A.F Maisessa ${ }^{1^{*}}$, Erviyenni $^{2}$, Susilawati $^{3}$ \\ ${ }^{1,2,3}$ Program Studi Pendidikan Kimia, Fakultas Keguruan dan Ilmu Pendidikan, Universitas Riau, \\ Indonesia \\ alfajrraviqa@gmail.com
}

\begin{abstract}
The role of technology in education is very important in helping to achieve learning goals, especially during a pandemic like now. This research aims to develop teaching materials in the form of an interactive electronic module or e-Module on the colligative properties of solutions using Sigil. The output of Sigil's products has an ePub format that is easily accessible both offline and online. This teaching material contains videos and animations to help visualize the concept. The research method used Research and Development by following the Plomp model. e-Module has been validated by 2 material experts and 2 media experts, and trials of users to teachers and students. The results showed that the interactive eModule has a very valid value of 4 assessment substances in the form of material substance, learning design, display (visual communication) and software utilization with a percentage of scores of $96.15 \%$, $96.88 \%, 93.75 \%$, and $95.19 \%$ respectively. The test results of user response each obtained a score of $96.67 \%$ with a very interesting category.
\end{abstract}

Keywords: colligative properties ; e-Module; ePub; interactive; Sigil.

\begin{abstract}
Abstrak
Peranan teknologi dalam pendidikan sangat penting dalam membantu tercapainya tujuan pembelajaran, terlebih pada masa pandemi seperti sekarang. Penelitian ini bertujuan untuk mengembangkan bahan ajar dalam bentuk modul elektronik atau $e$-Module yang bersifat interaktif pada materi sifat koligatif larutan menggunakan Sigil. Luaran dari produk Sigil memiliki format ePub yang mudah diakses secara offline maupun online. Bahan ajar ini dilengkapi dengan video dan animasi untuk membantu memvisualisasi konsep. Metode penelitian yang digunakan adalah Research and Development dengan mengikuti model Plomp. e-Module yang dikembangkan telah divalidasi oleh 2 ahli materi dan 2 ahli media, serta uji coba terhadap pengguna, yaitu guru dan peserta didik. Hasil penelitian menunjukkan bahwa $e$-Module interaktif yang dikembangkan memenuhi kriteria sangat valid dari 4 substansi penilaian yaitu substansi materi, desain pembelajaran, tampilan (komunikasi visual) dan pemanfaatan software dengan persentase skor berturut-turut sebesar 96,15\%, 96,88\%, 93,75\%, dan 95,19\%. Hasil uji respon pengguna masing-masing diperoleh skor $96,67 \%$ dengan kategori sangat menarik.
\end{abstract}

Kata Kunci: $e$-Module; ePub; interaktif; sifat koligatif larutan; Sigil.

Permalink/DOI: http://doi.org/10.15408/es.v13i2.21642 


\section{PENDAHULUAN}

Pelaksanaan pembelajaran hendaknya dapat terselenggara sesuai arahan dari Peraturan Pemerintah RI No 57 Tahun 2021 pasal 10 ayat (2) huruf $b$, yang menyatakan bahwa peserta didik harus termotivasi untuk berpartisipasi aktif, kreatif, serta mandiri dalam suasana belajar yang interaktif dan inspiratif sesuai dengan kemampuan dan latar belakangnya.

Karakteristik pembelajaran kimia menurut Herawati \& Muhtadi (2018) ialah berpusat pada sifat zat atau materi yang berukuran mikroskopis sehingga peserta didik membutuhkan media atau alat bantu untuk mempelajari materi kimia dengan benar. Salah satu materi kimia yang membutuhkan visualisasi adalah sifat koligatif larutan.

Sumari et.al (2021) dalam penelitiannya menyebutkan tingkat pemahaman konsep sifat koligatif larutan peserta didik kelas XII cenderung lebih rendah dibandingkan pemahaman hitungannya. Anugerah et.al (2015) menyatakan bahwa konsep penting dalam mempelajari sifat koligatif larutan adalah adanya gaya antarpartikel dan perubahan fase. Penting kiranya kehadiran media untuk memvisualisasikan konsep-konsep sifat koligatif larutan tersebut.

Observasi dan wawancara terstruktur bersama guru kimia kelas XII di SMAN 8 Pekanbaru dan SMAN 5 Pekanbaru dilakukan dengan tujuan untuk melihat kondisi proses pembelajaran yang terjadi. Hasil kegiatan ini ditemukan fakta bahwa bahan ajar pada materi sifat koligatif larutan masih terpusat pada buku cetak, buku soal, modul, dan power point. Proses pembelajaran di sekolah ini belum memanfaatkan bahan ajar digital yang interaktif dalam proses pembelajaran.

Penggunaan bahan ajar dalam bentuk $e$ Module interaktif dipandang tepat untuk pembelajaran individual maupun kelompok sehingga peserta didik dapat belajar dengan atau tanpa didampingi oleh guru. Hadirnya e-Module ini diharapkan dapat membantu guru dalam mengajar secara daring di situasi pandemi ataupun setelah pandemi ini berakhir. Bagi peserta didik dapat terbantu untuk lebih mudah mengakses bahan ajar yang interaktif dan bisa digunakan di mana dan kapan saja.

Pandemi Covid-19 telah mengubah sistem belajar langsung (luar jaringan) menjadi pembelajaran jarak jauh (dalam jaringan). Guru maupun peserta didik mengalami kesulitan mendapatkan bahan ajar yang cocok digunakan selama pembelajaran jarak jauh. Salah satu solusi yang dapat dilakukan untuk mengatasi keadaan tersebut ialah perlu adanya bahan ajar yang efektif dalam proses pembelajaran. Peneliti tertarik untuk mengembangkan bahan ajar yang dapat digunakan kapanpun, dimanapun, dan bersifat interaktif dalam mempelajari pokok bahasan berupa modul elektronik (e-Module) interaktif.

Pengembangan e-Module sejalan dengan prinsip pembelajaran yang dijelaskan dalam Permendikbud No 22 Tahun 2016 bahwa pembelajaran hakikatnya bisa dilaksanakan tanpa batas, baik batas waktu maupun tempat. Penggunaan teknologi informasi dan komunikasi yang tepat akan lebih efisien dan efektif dalam proses pembelajaran.

Modul termasuk salah satu bahan ajar dapat di-upgrade dengan bahan ajar multimedia interaktif menjadi bentuk e-Module (Putra et al, 2017). eModule merupakan versi elektronik dari modul sebagai bahan ajar mandiri yang disusun secara sistematis menjadi beberapa unit pembelajaran yang antar unitnya dapat diakses dengan bantuan navigasi untuk memberikan suasana pembelajaran yang interaktif antara peserta didik dan sumber belajar (Direktorat Pembinaan SMA, 2018). Adanya interaktifitas atau umpan balik dalam bahan ajar akan memfasilitasi peserta didik untuk belajar sesuai dengan kecepatannya masing-masing (Wibawanto, 2017).

Darma et.al (2019) dalam penelitiannya menyebutkan bahwa telah banyak format $e$-Book yang dikembangkan saat ini, namun format yang dapat menyesuaikan tampilan $e$-Book ataupun $e$ Module dengan ukuran layar perangkat yang digunakan oleh pengguna adalah ePub, salah satu software ePub adalah Sigil. Bahan ajar digital dapat diatur dan dirancang secara offline menggunakan Sigil (Tobing et al, 2020). Hal ini didukung oleh 
Rustaman et.al (2019) yang menyatakan jika format ePub menyediakan fitur yang lebih lengkap, di antaranya bisa menyisipkan video dan audio. Fitur ini tentunya akan lebih memberikan pengalaman belajar yang lebih baik.

Selain kelebihan bagi pengembang tersebut, pemilihan Sigil sebagai aplikasi pengembangan $e$ Module juga didasarkan pada kemudahan akses luaran atau produk akhir oleh pengguna. Sejalan dengan Merita (2018), bahwa format ePub bagi penggunan mempunyai kelebihan lain yaitu sudah tersedianya banyak aplikasi pembaca ePub (ePub reader) di berbagai perangkat elektronik, seperti komputer dapat diakses di google chrome, plugin firefox, jika menggunakan Android dengan menggunakan Reasily, Lithium, Ideal reader, PocketBook, iOS dapat menggunakan aplikasi ireader, Blackberry playbook, Sony Reader, dan berbagai perangkat lainnya. Tidak seperti buku teks yang penggunaannya terbatas, bahan ajar digital dalam bentuk e-Module melalui Sigil ini menurut Imansari et.al (2019) dapat juga menjadi sumber belajar yang lebih dinamis untuk belajar di rumah atau di luar sekolah. Penggunaan media pembelajaran berbasis Sigil dapat meningkatkan produktivitas pembelajaran dan media pembelajaran dapat menjadi alat bantu untuk membuat efektifitas dan efisiensi pembelajaran (Nafi'ah et al, 2019).

Penelitian yang sejalan dengan pengembangan bahan ajar menggunakan Sigil pernah diteliti oleh Yeni, dkk (2019) berjudul "Pengembangan E-Modul Interaktif Berbasis Android Menggunakan Sigil Software pada Materi Listrik Dinamis" yang memperoleh skor kualitas kemenarikan $83,33 \%$, kemudahan penggunaan $95,83 \%$, dan kemanfaatan 91,67\%. Hal ini memperlihatkan e-Modul interaktif menggunakan Sigil Software dinilai menarik, mudah digunakan, dan bermanfaat dalam meningkatkan pemahaman.

Penelitian terkait pengembangan sumber belajar digital sifat koligatif larutan pernah dilakukan oleh Kiki Ledya pada tahun 2020 berupa aplikasi media pembelajaran yang dapat diunduh pada playstore, namun belum terdapat uraian materi yang jelas dan tingkat interaktivitas yang masih rendah. Penelitian relevan lainnya dilakukan oleh
Nita dan Ali (2018) terkait modul elektronik (eModul) interaktif asam dan basa yang diperoleh hasil kategori layak oleh ahli media serta untuk respon pengguna, penerapan dan penggunaan $e$ Modul dalam pembelajaran mendapat kriteria layak dan respon positif dari peserta didik.

Hadirnya $e$-Module interaktif sifat koligatif larutan menggunakan aplikasi Sigil ini diharapkan dapat membantu guru dalam mengajar secara daring di situasi pandemi ataupun setelah pandemi ini berakhir. Bagi peserta didik dapat terbantu untuk lebih mudah mengakses bahan ajar yang interaktif dan bisa digunakan di mana dan kapan saja.

\section{METODE}

Penelitian yang dilakukan di Program Studi Pendidikan Kimia Universitas Riau, SMA Negeri 8 Pekanbaru, dan SMA Negeri 5 Pekanbaru ini termasuk ke dalam jenis penelitian research and development (R\&D) dengan berpedoman pada model Plomp. Model Plomp memiliki 5 fase, yaitu fase investigasi awal, desain, realisasi/konstruksi, validasi, tes, dan revisi, serta implementasi.

Model Plomp dipandang cocok untuk mengembangkan $e$-Module interaktif sifat koligatif larutan menggunakan aplikasi Sigil. Setiap fase pengembangan dalam model Plomp berisi kegiatan pengembangan yang dapat diintervensi atau disesuaikan dengan karakteristik penelitian yang akan dilakukan. Model Plomp dipandang lebih luwes dan fleksibel dalam mengembangkan $e$ Module interaktif sifat koligatif larutan menggunakan aplikasi Sigil yang membutuhkan optimalisasi dalam intervensi peneliti di setiap proses. Hal ini didukung oleh pernyataan Ratih (2016) dalam penelitiannya yang berjudul Pengembangan Model Problem Creating Setting Peer Learning Untuk Meningkatkan Kemampuan Berpikir Kreatif.

Penelitian ini hanya terbatas sampai fase keempat uji coba terbatas atau skala kecil untuk mengetahui respon pengguna karena tujuan penelitian hanya sampai tahap mengembangkan dan adanya keterbatasan. Setiap tahapan yang telah dilaksanakan dapat dilihat pada Gambar 1. 


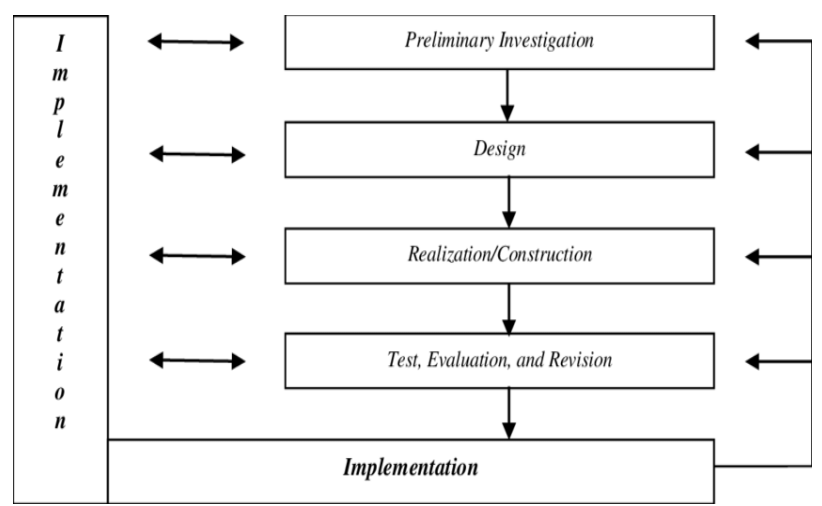

Gambar 1. Tahapan Model Plomp (Plomp, 1997)

Gambar 1 menjelaskan pada setiap fase, diperlukan validasi oleh tim untuk memastikan tahapan pengembangan produk telah dilakukan dengan tepat. Validasi oleh ahli serta uji coba kepada pengguna ditujukan untuk mengetahui tingkat kevalidan/kelayakan produk yang dikembangkan sebagai alternatif sumber belajar.

Subjek dalam penelitian ini adalah guru dan peserta didik dari SMA Negeri 8 Pekanbaru dan SMA Negeri 5 Pekanbaru sebagai responden uji coba, sedangkan objek penelitian berupa e-Module interaktif sifat koligatif larutan menggunakan aplikasi Sigil untuk kelas XII SMA/MA yang dikembangkan mengikuti pedoman model pengembangan Plomp.

Instrumen pengumpul data yang digunakan dalam penelitian ini berupa lembar validasi dan kuesioner respon pengguna. Lembar validasi ditujukan untuk mengetahui tingkat kelayakan produk dari segi materi dan media yang dinilai oleh 2 ahli materi dan 2 ahli media. Kisi-kisi lembar validasi terdiri dari 4 aspek, diantarnya aspek substansi materi (kebenaran, kedalaman, kekinian, dan keterbacaan), desain pembelajaran (halaman sampul, penyusun, tujuan pembelajaran, indikator pencapaian kompetensi, materi pembelajaran, contoh soal, latihan, evaluasi akhir pembelajaran, tindak lanjut, referensi), aspek tampilan komunikasi visual (navigasi, tipografi, media, warna, animasi, dan layout), serta aspek pemanfaatan software (interaktifivitas, software pendukung, dan originalitas). Respon guru dan peserta didik selaku pengguna diperoleh melalui uji coba dan kuesioner respon pengguna.
Teknik pengumpulan data yang digunakan ialah studi literatur dan studi lapangan yang dilaksanakan mulai dari fase investigasi awal hingga uji coba terbatas. Studi literatur dimaksudkan untuk menelusuri informasi penguat yang relevan, sementara studi lapangan untuk memperoleh data terkait kondisi pembelajaran, validitas, serta respon pengguna. Teknik analisis data yang digunakan berupa analisis validitas dan analisis respon pengguna. Lembar validasi menggunakan skala pengukuran sikap dengan skor 1-4 untuk menghindari pemilihan poin yang bersifat netral. Alternatif pernyataan positif sikap diubah ke dalam bentuk skor menggunakan skala empat pilihan Likert agar diperoleh data kuantitatif yang dapat dilihat pada Tabel 1.

Tabel 1. Skor Alternatif Pernyataan Positif

\begin{tabular}{cc}
\hline Pernyataan Sikap & Skor \\
\hline Setuju (S) & 4 \\
Cukup Setuju (CS) & 3 \\
Kurang Setuju (KS) & 2 \\
Tidak Setuju (TS) & 1 \\
\hline
\end{tabular}

(Sugiyono, 2019)

Rumus yang digunakan untuk mengolah data validasi dan respon pengguna (Liana et al, 2019) adalah sebagai berikut:

$$
P=\frac{\sum \text { skor perolehan }}{\sum \text { skor maksimum }} \times 100 \%
$$

Hasil persentase skor validasi yang diperoleh diinterpretasikan dalam kriteria validasi seperti pada Tabel 2. Sementara hasil persentase skor respon pengguna mengacu pada Tabel 3 .

Tabel 2. Kriteria Validitas

\begin{tabular}{cc}
\hline Persentase Skor & $\begin{array}{c}\text { Kriteria } \\
\text { Validitas }\end{array}$ \\
\hline $85,01-100,00$ & Sangat Valid \\
$70,01-85,00$ & Cukup Valid \\
$50,01-70,00$ & Kurang Valid \\
$01,00-50,00$ & Tidak Valid \\
\hline
\end{tabular}

(Akbar, 2015)

Tabel 3. Kriteria Respon Pengguna

\begin{tabular}{cc}
\hline Persentase Skor & Kriteria Respon \\
& Pengguna \\
\hline $81,00-100,00$ & Sangat Menarik \\
$61,00-80,00$ & Menarik \\
$41,00-60,00$ & Cukup Menarik \\
$21,00-40,00$ & Tidak Menarik \\
$0,00-20,00$ & Sangat Tidak Menarik \\
\hline
\end{tabular}

(Riduwan, 2015) 


\section{HASIL DAN PEMBAHASAN}

Penelitian pengembangan yang telah dilakukan menghasilkan sebuah produk berupa $e$ Module interaktif sebagai bahan ajar digital pada materi sifat koligatif larutan. Luaran dari produk yang dikembangkan menggunakan Sigil berformat ePub. e-Module dengan format ePub dapat diakses oleh pengguna dengan mengunduh aplikasi pembaca ePub (ePub reader).

Prosedur pengembangan $e$-Module interaktif sifat koligatif larutan menggunakan aplikasi Sigil berpedoman pada model pengembangan Plomp. Berikut penjelasan mengenai hasil dari setiap tahapan dalam pengembangan $e$-Module interaktif sifat koligatif larutan.

\section{Fase Investigasi Awal (Preliminary Investigation)}

Fase investigasi awal bertujuan untuk menganalisis ruang lingkup pengembangan $e$ Module interaktif ini yang terdiri dari analisis ujung depan, peserta didik, materi dan kompetensi. Analisis ujung depan dilakukan dengan cara observasi, wawancara terstruktur dengan guru, dan telaah literatur. Hasil dari analisis ini diperoleh data bahwasannya dalam pembelajaran sifat koligatif larutan belum menggunakan bahan ajar digital yang mampu memvisualisasikan konsep. Penggunaan bahan ajar sejauh ini terpusat pada buku cetak, buku soal, dan modul. Kementrian Pendidikan dan Kebudayaan (2017) menyatakan bahwa salah satu dari kemampuan abad 21 adalah terampil menggunakan media TIK dalam proses pembelajaran.

Analisis peserta didik dilakukan melalui angket google form kepada 62 peserta didik kelas XII. Sebanyak 64,5\% menyatakan sifat koligatif larutan sulit dari segi konsep dan 35,5\% sulit dari segi hitungan. Tingkat pemahaman peserta didik responden konsep sifat koligatif larutan hanya $47,47 \%$, sedangkan pemahaman tentang perhitungan sifat koligatif larutan mencapai $88,3 \%$. Sumber bacaan yang peserta didik miliki berupa buku paket dan slide power point dan media yang sering digunakan guru dalam proses pembelajaran adalah papan tulis dan in focus. $72,5 \%$ peserta didik merasa kurang memahami materi dengan sumber bacaan dan media yang digunakan selama ini, $17,7 \%$ merasa tidak dapat memahami, dan $9,67 \%$ menyatakan dapat memahami sifat koligatif larutan dengan sumber bacaan dan media yang sudah ada. Mengenai ketertarikan peserta didik terhadap sumber belajar dan media yang digunakan, sebanyak $80,6 \%$ peserta didik kurang tertarik, $16,2 \%$ tidak tertarik, dan 3,2\% tertarik. Kehadiran e-Module interaktif menurut Syamsurizal et.al (2015) mempermudah peserta didik untuk menguasai materi pembelajaran karena akses yang mudah serta ada nya umpan balik atau interaksi antara bahan ajar dan peserta didik secara langsung.

Analisis kompetensi menghasilkan rumusan tujuan pembelajaran dan indikator pencapaian kompetensi yang mengacu pada kompetensi dasar 3.1, 4.1, 3.2, dan 4.2 pada silabus. Pentingnya tahapan ini didukung oleh Muhidin \& Al Faruq (2018) yang menyatakan analisis ini perlu guna menentukan kompetensi-kompetensi kecil menjadi bagian dari capaian pembelajaran agar peserta didik dapat menyusun dan memahami sebuah materi sesuai dengan alurnya. Analisis materi menghasilkan penjabaran telaah konsep-konsep sifat koligatif larutan beserta peta konsep.

\section{Fase Desain (Design)}

Hasil dari kegiatan pada fase ini berupa rancangan prototipe dan instrumen penelitian. Hasil rancangan prototipe berupa $e$-Module interaktif sifat koligatif larutan menggunakan aplikasi Sigil. e-Module dirancang memiliki gambar, animasi, serta video untuk membantu memvisualisasi konsep serta memberikan pengalaman belajar yang menyenangkan. Perancangan ini sejalan dengan Agustiningsih (2015) yang menyatakan penggunaan video sangat efektif dalam menunjang pembelajaran. Pembelajaran berbasis komputer menurut Japar (2018) akan meningkatkan pemahaman peserta didik jika disusun dengan menyeleksi materi secara benar dan representatif melalui penggunaan animasi, video, simulasi, demonstrasi, dan lainnya

Hasil rancangan instrumen penelitian berupa lembar validasi yang berpedoman pada Panduan Pengembangan Bahan Ajar Berbasis TIK oleh Direktorat Pembinaan SMA (2010) yang memuat 
komponen penilaian berupa aspek substansi materi, desain pembelajaran, tampilan (komunikasi visual), dan pemanfaatan software yang disesuaikan dengan topik penelitian. Kuesioner respon pengguna diperoleh dan dirancang sesuai dengan kebutuhan penelitian berdasarkan literatur yang relevan.

\section{Fase Realisasi/Konstruksi (Realization/Construction)}

Rancangan yang dihasilkan pada fase desain direalisasikan pada fase ini. konten dalam $e$-Module interaktif sifat koligatif larutan yang dimodifikasi dari Panduan Penyusunan Praktis e-Module oleh (Direktorat Pembinaan SMA, 2018). Karakteristik desain pembelajaran suatu e-Module interaktif adalah yang memenuhi representasi isi dengan bantuan unsur animasi dan video yang dibuat agar lebih interaktif, menggunakan tipe-tipe pembelajaran yang bervariasi seperti tutorial, simulasi, dan latihan, adanya respon terhadap stimulus yang diberikan oleh peserta didik, serta kemandirian dan prinsip self evaluation (Safitri et $a l, 2019)$.

Sejalan dengan pendapat di atas, adapun konten yang terdapat dalam e-Module ini yaitu, halaman sampul, daftar isi, pendahuluan yang berisi penjabaran kompetensi dasar, tujuan pembelajaran, indikator pencapaian kompetensi, deskripsi $e$ Module dan materi, dan petunjuk penggunaan $e$ Module, tiga Kegiatan Pembelajaran yang masingmasing berisi Uraian materi disertai gambar, video, dan animasi, contoh soal, Chemistry info, Latihan dan penilaian diri interaktif. LKPD terdapat pada kegiatan pembelajaran 2 yang disertai virtual laboratory. Bagian akhir berisi penugasan, Evaluasi akhir/Tes sumatif interaktif, Glosarium, dan daftar pustaka. Realisasi desain intrumen penelitian menghasilkan lembar validasi materi dan media serta kuesioner respon pengguna untuk guru dan peserta didik beserta rubrik penilaian.

\section{Fase Validasi, Uji Coba, dan Revisi (Test, Evaluation, and Revision)}

Tahapan ini merupakan tahapan akhir dari pengembangan $e$-Module interaktif sifat koligatif larutan menggunakan aplikasi Sigil. Validasi merupakan tahapan yang sangat penting dilakukan untuk mengetahui kelayakan produk yang dikembangkan sebelum diuji coba kepada pengguna. Revisi dilakukan setiap setelah validasi dan uji coba berdasarkan masukan dari validator dan partisipan hingga diperoleh prototipe akhir.

\section{Validasi}

e-Module interaktif sifat koligatif larutan divalidasi oleh 2 ahli materi dan 2 ahli media. Aspek yang dinilai oleh ahli materi terdiri dari substansi materi dan desain pembelajaran, sedangkan ahli media berfokus pada aspek tampilan (komunikasi visual) dan pemanfaatan software. Perbaikan dan saran diperoleh pada validasi I agar dihasilkan produk yang lebih baik. Adapun perbaikan dari validator materi terkait kebenaran konsep animasi dapat dilihat pada Gambar 2 (sebelum revisi) dan Gambar 3 (sesudah revisi)

Produk yang telah direvisi sesuai saran diberikan kembali kepada validator untuk dilakukan validasi kedua. Skor 96,15\% dengan kriteria sangat valid untuk aspek substansi materi diperoleh pada validasi kedua dan menunjukkan jika penyajian materi telah sesuai dengan konsep yang ada. Hal ini sejalan dengan penelitian Yeni, dkk (2019) yang menyatakan miskonsepsi akan dapat dihindari apabila materi yang disajikan sesuai dengan teori yang ada serta mampu menyederhanakan materi yang kompleks. Penelitian Khoiriah (2016) juga menambahkan pemanfaatan multimedia dalam pembalajaran IPA berdampak positif terhadap tingkat kognitif peserta didik.

Produk yang telah direvisi sesuai saran divalidasi kembali dan diperoleh nilai 96,88\% dengan kriteria sangat valid. Skor ini menunjukkan bahwa rancangan desain pembelajaran telah tersusun dan dikemas dengan baik sebagai suatu bahan ajar bagi peserta didik. Hasil ini sejalan dengan temuan Arike, dkk (2019) bahwa karakteristik desain pembelajaran suatu $e$-Module interaktif adalah yang memenuhi representasi isi dengan bantuan unsur animasi dan video yang dibuat agar lebih interaktif, menggunakan tipe-tipe pembelajaran yang bervariasi seperti tutorial, simulasi, dan latihan, adanya respon terhadap stimulus yang diberikan oleh peserta didik, serta kemandirian dan prinsip self evaluation. 


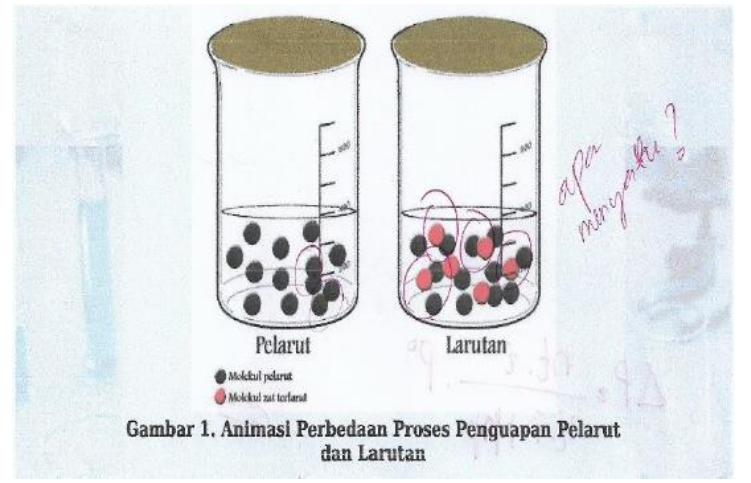

Gambar 2. Tampilan Validasi Materi Sebelum Revisi

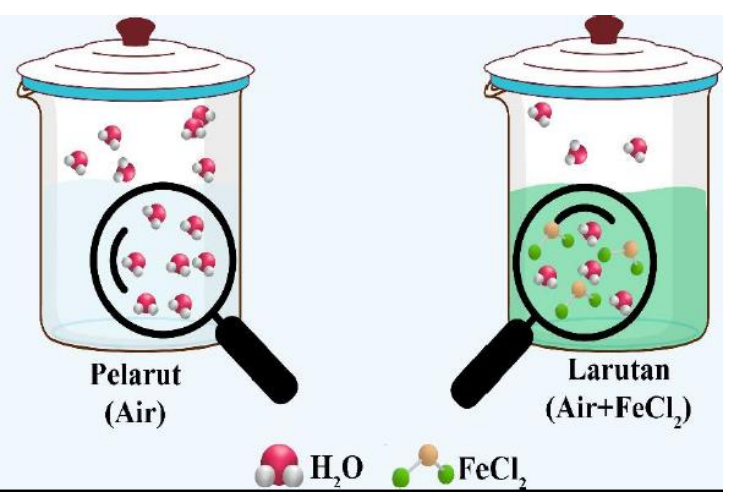

Gambar 3. Tampilan Validasi Materi Sesudah Revisi

Produk yang telah direvisi sesuai saran diberikan kembali kepada validator untuk dilakukan validasi kedua dan diperoleh nilai kelayakan 93,75\% dengan kategori sangat valid. e-Module dengan tingkat kelayakan ini menurut Komang (2018) mampu memicu ketertarikan dan keterlibatan siswa dalam belajar karena didesain secara menarik dan sederhana. Penyampaian materi tidak hanya mengandalkan aspek teks, tetapi juga didukung dengan komponen-komponen multimedia seperti gambar, video, dan animasi.

Perbaikan dari validator media terkait komposisi warna pada halaman sampul dapat dilihat pada Gambar 4 (sebelum revisi) dan Gambar 5 (sesudah revisi).

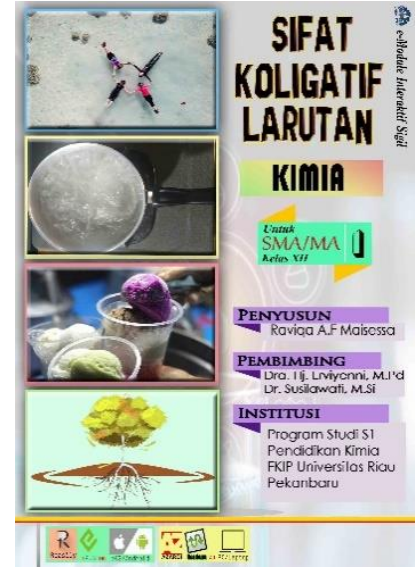

Gambar 4. Tampilan Validasi Media Sebelum Revisi

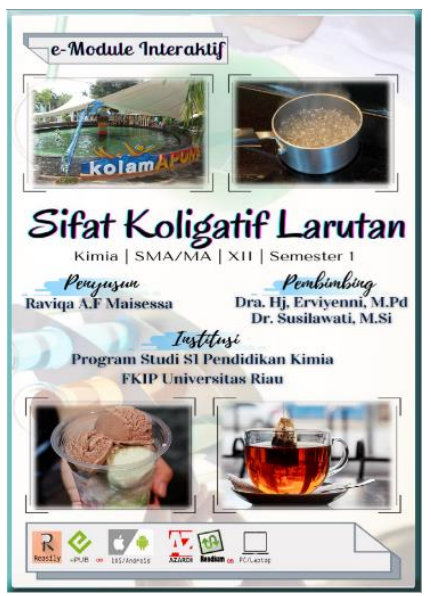

Gambar 5. Tampilan Validasi Media Sesudah Revisi

Hasil validasi II $e$-Module interaktif sifat koligatif larutan yang dikembangkan secara keseluruhan aspek, mendapatkan skor penilaian 95,49\%. Skor ini berada pada rentang $85,01 \%$ $100 \%$ dengan kategori sangat valid. Hasil dari keseluruhan validasi setiap aspek dapat dilihat pada Tabel 4.

Tabel 4. Hasil Validasi Materi dan Media

\begin{tabular}{ccc}
\hline No & $\begin{array}{c}\text { Aspek } \\
\text { Penilaian }\end{array}$ & $\begin{array}{c}\text { Skor } \\
(\mathbf{\%})\end{array}$ \\
\hline 1. & Substansi Materi & 96,15 \\
2. & Desain Pembelajaran & 96,88 \\
3. & Tampilan (Komunikasi Visual) & 93,75 \\
4. & Pemanfaatan Software & 95,19 \\
& Rata-Rata (\%) & $\mathbf{9 5 , 4 9}$ \\
\hline & Kriteria & Sangat Valid \\
\hline
\end{tabular}

Gambar 6 menyajikan perbandingan skor validasi I dan II dari ahli materi substansi materi dan desain pembelajaran) serta ahli media \{tampilan (komunikasi visual) dan pemanfaatan software . 


\section{DIAGRAM PERSENTASE SKOR VALIDASI}

"Validasi I "Validasi II

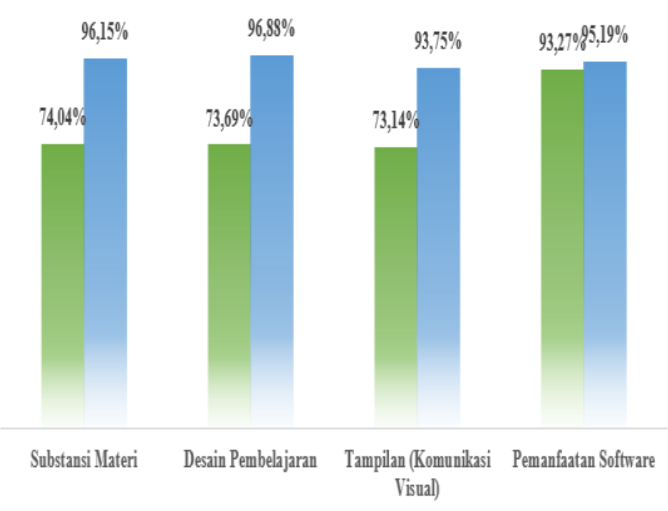

Gambar 6. Perbandingan Skor Validasi I dan II

\section{Uji Coba}

e-Module yang telah mendapatkan kriteria valid baik dari validator materi dan media selanjutnya dilakukan uji satu-satu dan uji respon pengguna, yang terdiri dari guru kimia dan peserta didik kelas XII SMA yang telah mempelajari materi sifat koligatif larutan.Uji satu-satu dilakukan kepada 3 orang peserta didik dengan gradien kompetensi. Berdasarkan pengamatan, tidak ada peserta didik yang mengalami kesulitan berarti baik dari segi penggunaan media ataupun materi dalam e-Module. Rusdi (2018) menyatakan pentingnya uji satu-satu untuk memberikan peneliti kesempatan berinteraksi dan melakukan tanya jawab dengan responden terkait kekurangan dan kelebihan dari produk.

Uji respon guru dilakukan kepada 3 orang guru kimia dengan rincian 2 orang guru kimia kelas XII di SMA Negeri 8 Pekanbaru 1 orang guru kimia kelas XII di SMA Negeri 5 Pekanbaru yang memperoleh skor $96,67 \%$ dengan kategori sangat menarik. Uji kelompok kecil dilakukan kepada 18 orang peserta didik secara daring dan juga mendapatkan skor 96,67\% (sangat menarik). Hasil ini sejalan dengan Rusdi (2018) yang mengatakan bahwa pelaksanaan uji coba kelompok kecil bertujuan untuk mendapatkan kepastian bahwa partisipan dapat menggunakan produk tanpa kehadiran perancang, sehingga e-Module dapat digunakan dalam proses pembelajaran.

\section{Revisi}

Revisi dilakukan berdasarkan perbaikan dan komentar dari validator ahli materi dan media, responden peserta didik uji satu-satu, guru responden, serta peserta didik uji kelompok kecil hingga diperoleh prototipe final yang valid dan mendapat respon dengan kriteria sangat menarik. Damanik et.al (2020) dalam penelitiannya juga menemukan jika penggunaan $e$-Module berbasis Sigil sangat membantu peserta didik dalam belajar karena bahan ajar yang telah dilengkapi dengan teks, gambar, dan video sehingga peserta didik tertarik untuk memahami materi dan dapat memotivasi peserta didik untuk belajar mandiri tanpa bimbingan guru secara langsung.

\section{PENUTUP}

Pengembangan $e$-Module interaktif sifat koligatif larutan menggunakan aplikasi Sigil yang valid menurut validator materi dan media telah dikembangkan melalui prosedur model pengembangan Plomp dan didapatkan hasil dengan kategori valid/layak. Kategori kelayakan tersebut terdiri dari 4 substansi penilaian yaitu substansi materi, desain pembelajaran, tampilan (komunikasi visual) dan pemanfaatan software dengan persentase skor penilaian berturut-turut sebesar $96,15 \%, 96,88 \%, 93,75 \%$, dan 95,19\%. Respon dari 3 orang guru kimia sebagai pengguna mendapatkan skor persentase rata-rata sebesar $96,67 \%$ dengan kategori sangat menarik serta respon 18 orang peserta didik terhadap juga memperoleh skor persentase rata-rata sebesar $96,67 \%$ dengan kategori sangat menarik. e-Module interaktif sifat koligatif larutan menggunakan aplikasi Sigil sebagai salah satu bahan ajar yang dapat digunakan dalam proses pembelajaran dengan mempertimbangkan peralatan pendukung yaitu gadget, laptop atau komputer.

\section{UCAPAN TERIMA KASIH}

Terimakasih peneliti ucapkan kepada pihak yang terlibat dan mendukung terealisasinya penelitian pengembangan ini, diantaranya dosen validator, dosen penguji, guru dan peserta didik kelas XII di SMA Negeri 8 Pekanbaru dan SMA Negeri 5 Pekanbaru, serta pihak-pihak lain yang telah membersamai hingga saat ini. 


\section{DAFTAR PUSTAKA}

Agustiningsih, A. (2015). Video Sebagai Alternatif Media Pembelajaran Dalam Rangka Mendukung Keberhasilan Penerapan Kurikulum 2013 di Sekolah Dasar. PEDAGOGIA: Jurnal Pendidikan, 4(1), 50. https://doi.org/10.21070/pedagogia.v4i1.72

Akbar, S. (2015). Instrumen Perangkat Pembelajaran. Remaja Rosdakarya.

Anugerah, Sukma Hadi, Effendy, dan Suharti. (2015). Analisis Kesalahan Konsep Sifat Koligatif Larutan Pada Mahasiswa Kimia Universitas Negeri Malang Dan Eliminasinya Menggunakan Media Visualisasi Statik. Jurnal Ilmu Pendidikan 21(2)

Arike Ikhfa Safitri, Festiyed Amali Putra, dan Fatni Mufit. (2019). Desain Modul Interaktif Menggunakan Aplikasi Course Lab Berbasis Pendekatan Saintifik Pada Materi Usaha, Energi, dan Momentum. Pillar of Physics Education 12(3). Universitas Negeri Padang. Padang.

Azhar, E., \& Kusumah, Y. S. (2011). Pengembangan Perangkat Pembelajaran Teori Peluang Berbasis RME untuk Meningkatkan Pemahaman, Penalaran, dan Komunikasi Matematik Siswa SLTA. Prosiding Seminar Nasional Matematika Dan Pendidikan FMIPA UNY,612-621. https://eprints.uny.ac.id/7374/1/p-19.pdf

Damanik T.M., Hutasuhut, S., \& Fitrawaty. (2020). The Development of E-Module to Improve Learning Results Introduction to Accounting I. Budapest International Research and Critics in Linguistics and Education (BirLE) Journal. Volume 3 (4). https://doi.org/10.33258/birle.v3i4.1496

Darma, R.S., Setyadi, A., Wilujeng, I., Jumadi, \& Kuswanto, H. (2019). Multimedia Learning Module Development based on SIGIL Software in Physics Learning. International Seminar on Science Education. IOP Conf. Series: Journal of Physics: Conf. Series
1233. https://doi.org/10.1088/17426596/1233/1/012042

Direktorat Pembinaan SMA. (2010). Panduan Pengembangan Bahan Ajar Berbasis TIK. Kementerian Pendidikan Nasional.

Direktorat Pembinaan SMA. (2018). Panduan Praktis Penyusunan E-Modul. Kementerian Pendidikan Nasional Direktorat Pembinaan Sekolah Menengah Atas.

Herawati, N. S., \& Muhtadi, A. (2018). Pengembangan modul elektronik (e-modul) interaktif pada mata pelajaran Kimia kelas XI SMA. Jurnal Inovasi Teknologi Pendidikan, 5(2), 180-191. https://doi.org/10.21831/jitp.v5i2.15424

Imansari A, Umamah N, dan M Na'im. (2019). The Usage Of e-Book As Learning Media Through The Sigil Application In History. IOP Conf. Series: Earth and Environmental Science 243. https://doi.org/10.1088/17551315/243/1/012155

Japar, M. (2018). Teknologi dan Informasi Pendidikan. Jakarta:Laboratorium Sosial Politik Press.

Kementerian Pendidikan dan Kebudayaan. (2017). Panduan Implementasi Kecakapan Abad-21 Kurikulum 2013 di Sekolah Menengah Atas. Direktorat Jenderal Pendidikan Dasar dan Menengah.

Lestari, S. (2018). Peran Teknologi dalam Pendidikan di Era Globalisasi. Edureligia; Jurnal Pendidikan Agama Islam, 2(2), 94 100.

https://doi.org/10.33650/edureligia.v2i2.459

Liana, Y. R., Ellianawati, \& Hardyanto, W. (2019). Pengembangan E-Modul Interaktif Berbasis Android Menggunakan Sigil Software pada Materi Listrik Dinamis. Seminar Nasional Pascasarjana Universitas Negeri Semarang, 926-932.

Wijayanti, M. (2018). Pengembangan E-Book IPA Fisika Berbasis Program Sigil Peserta Didik SMPN 23 Simbang Kabupaten Maros. 
Seminar Nasional Fisika. Pascasarjana Universitas Negeri Makassar. Makassar.

Muhidin, A., \& Al Faruq, U. (2018). Pengembangan Bahan Ajar di Perguruan Tinggi. Tangerang:UNPAM Press.

Nafi'ah, U., Mashuri, dan Wijaya, D.N. (2019). The Development of Digital Book of European History to Shape the Students' Democratic Values. International Journal of Engineering and Techniques. Vol 14 (6). https://doi.org/10.3991/ijet.v14i06.9760

Plomp, T. (2009). Educational design research: Introduction. in T. Plomp, \& N. Nieveen (Eds.), An introduction to educational design research (pp.9-35). Enschede, (the Netherlands): SLO.

Putra, K. W. B., Wirawan, I. M. A., \& Pradnyana, G. A. (2017). Pengembangan E-Modul Berbasis Model Pembelajaran Discovery Learning Pada Mata Pelajaran "Sistem Komputer" Untuk Siswa Kelas X Multimedia Smk Negeri 3 Singaraja. Jurnal Pendidikan Teknologi Dan Kejuruan, 14(1), 40-49.

https://doi.org/10.23887/jptk.v14i1.9880

Puspasari, R. (2016). Pengembangan Model Problem Creating Setting Peer Learning Untuk Meningkatkan Kemampuan Berpikir Kreatif. Jurnal Pendidikan dan Pembelajaran Matematika, 2(1), 79-94.

Riduwan. (2015). Belajar Mudah Penelitian Untuk Guru - Karyawan dan Peneliti Pemula. Jakarta:Alfabeta.

Rusdi. (2018). Penelitian Desain dan Pengembangan Pendidikan. Jakarta:Raja Grafindo Persada.

Rustaman, A. H., Iqbal, M., \& Amelia, W. (2019). Pengembangan Modul Digital Praktikum Komputer Grafis 1 Dalam Format Elektonik Publication (EPUB) Untuk Meningkatkan Pemahaman Teknik Grafis Mahasiswa Desain Komunikasi Visual. Jurnal Ilmu Sosial Dan Pendidikan, 3(1), 224-229. http://ejournal.mandalanursa.org/index.php/J ISIP
Safitri, A. I., Festiyed, Putra, A., \& Mufit, F. (2019). Desain Modul Interaktif Menggunakan Aplikasi Course Lab Berbasis Pendekatan Saintifik Pada Materi Usaha Energi dan Momentum. Jurnal Pillar of Physics Education, 12(3), 433-440. of Physics Education, 12(3).

Sugiyono. (2019). Metode Penelitian Pendidikan. Jakarta:Alfabeta.

Fauziah, S.R, Sumari, Budiasih, E., Sukarianingsih, D., Santoso, A., dan Asrori, M.R. (2021). Student Misconsception Analysis on the Concept of Colligative Properties of Solutions Using a Digital Three Tier Multiple-Choice Diagnostic Test. AIP Conference Proceedings. 02 Maret 2021. https://doi.org/10.1063/5.0043415

Syamsurizal, Haryanto, \& Chairani, N. (2015). Pengembangan e-Modul Berbasis Keterampilan Proses Sains Pada Materi Kesetimbangam Kimia Untuk Tingkat SMA. Prosiding SEMIRATA, 655-661.

Tobing H.E.L., Somakim, Susanti, E. (2020). The Use of Electronic Modules Designed Using Sigil in Learning the Distance in Geometry. 4th Sriwijaya University Learning and Education International Conference (SULEIC 2020). Atlantis Press. Volume 513. https://doi.org/10.2991/assehr.k.201230.175

Wibawanto, W. (2017). Desain dan Pemograman Multimedia Pembelajaran Interaktif. Jember:Cerdas Ulet Kreatif.

Liana, Y.R., Ellianawati, dan Hardyanto, W. (2019). Pengembangan E-Modul Interaktif Berbasis Android Menggunakan Sigil Software pada Materi Listrik Dinamis. Prosiding Seminar Nasional Pascasarjana UNNES. 16 November 2019. Universitas Negeri Semarang. Semarang. 